\title{
SPONTANEOUS SUBARACHNOID HEMORRHAGE AS THE PRIMARY MANIFESTATION OF CAROTID CAVERNOUS FISTULAS
}

\section{Case report}

\author{
Clement Hamani, Almir Ferreira Andrade, \\ Eberval Gadelha Figueiredo, Orildo Ciquini Jr., Raul Marino Jr.
}

\begin{abstract}
We report the case of a 19-year old male patient initially admitted to our service after a motor vehicle accident with a normal neurologic evaluation and a CT scan that revealed no abnormalities. Nineteen months later, he was readmitted after a subtle headache episode, followed by a brief loss of consciousness. He was submitted to a complete evaluation, which revealed no abnormalities (even in the neurologic and ophthalmologic exams). A CT was performed revealing a diffuse subarachnoid hemorrhage. Contrast enhancement displayed a right paraselar lesion, which was first interpreted as a giant aneurysm. The patient underwent a cerebral angiography which showed a right carotid-cavernous fistula with retrograde venous drainage through the superior and inferior petrosal sinuses. Filling of various cortical vessels was observed. The patient was treated with endovascular technique and a control angiographic study assured the complete closure of the fistula. He had an excellent clinical recovery, being discharged in good conditions.
\end{abstract}

KEY WORDS: carotid cavernous fistula, subarachnoid hemorrhage, head injury.

\begin{abstract}
Hemorragia meníngea espontânea como manifestação inicial de fístula carótido-cavernosa: relato de caso
RESUMO - Apresentamos o caso de um paciente de 19 anos atendido em nosso Serviço de Emergência após um acidente com veículo automotor apresentando, exame neurológico e tomografia computadorizada de crânio normais. Passados dezenove meses, foi readmitido após episódio súbito de cefaléia e perda de consciência. Foi submetido a avaliação clínica (inclusive neurológica e oftalmológica) que não revelou anormalidades. Solicitada então nova tomografia computadorizada de crânio que desta vez mostrou hemorragia meníngea difusa e uma lesão para-selar com captação de contraste à direita, inicialmente encarada como um aneurisma gigante. A angiografia cerebral revelou uma fístula carótido cavernosa à direita, com fluxo retrógrado pelos seios petrosos superior e inferior, com enchimento venoso de vasos corticais. Optou-se pelo tratamento endovascular, cujo controle angiográfico mostrou o fechamento completo da fístula. O paciente evoluiu com melhora clínica recebendo alta a seguir.
\end{abstract}

PALAVRAS-CHAVE: fístula carótido cavernosa, hemorragia subaracnoide, traumatismo craniano.

Carotid cavernous fistulas (CCF) are characterized by an anatomic communication between the internal carotid artery (ICA) and the cavernous sinus. Several types have been distinguished among these entities, according to their etiology and arterial supply to the fistulas ${ }^{1}$. Traumatic fistulas are the most frequent forms, being generally characterized by an acute onset after a history of head injury. Notwithstanding, CCFs may present insidiously, achieving clinical significance over weeks or even months. Hereby, we will report a case of CCF which primarily presen- ted as a spontaneous subarachnoid hemorrhage two years after a mild traumatic event.

\section{CASE}

A 19-year old male patient was admitted to our service after a motor vehicle accident. He was submitted to a complete clinical and neurologic evaluation, which only presented a mandible fracture. A computed tomography was performed revealing no abnormalities. The patient was thereafter referred to the plastic surgery division for further treatment.

Division of Neurosurgery, Hospital das Clínicas, Faculdade de Medicina da Universidade de São Paulo, São Paulo SP, Brasil.

Received 3 January 2001, received in final form 23 March 2001. Accepted 29 March 2001. 


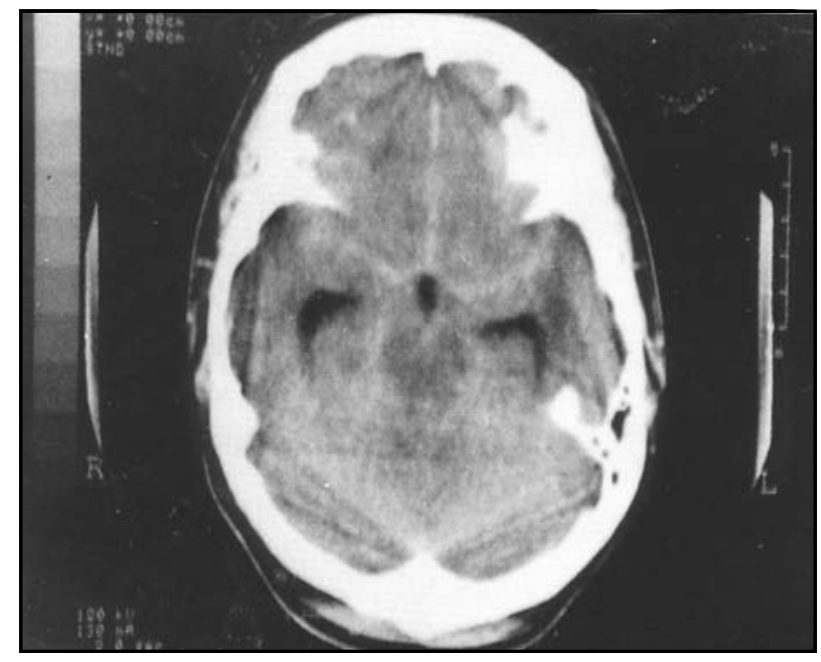

Fig 1. CT scan obtained after the patient admission revealing a diffuse subarachnoid hemorrhage.

Nineteen months later, he was readmitted to our service after a subtle headache episode, followed by a brief loss of consciousness, while he was driving a motorcycle. He was submitted to a complete trauma evaluation, which presented no abnormalities. At arrival, he had already recovered consciousness and was in GCS 15. The patient presented a normal neurologic and ophthalmologic exam. After clinical evaluation, a computed tomography was promptly performed, revealing a diffuse subarachnoid hemorrhage (Fig 1). Contrast enhancement displayed a right paraselar lesion, which was first interpreted as a giant aneurysm (Fig 2).
The patient was underwent a cerebral angiography which revealed the presence of a right carotid-cavernous fistula with retrograde venous drainage through the superior and inferior petrosal sinuses. Filling of various cortical vessels was observed. No venous drainage was seen through the ophthalmic vein (Fig 3).

A detachable BALT balloon was introduced, via transfemoral technique, into the cavernous sinus, where it was inflated and detached. A control angiographic study assured the complete closure of the fistula and the maintenance of the normal permeability of the carotid artery. The patient had an excellent clinical recovery, being discharged in good clinical conditions.

\section{DISCUSSION}

In the present study, we report a case of a young male patient who developed a spontaneous subarachnoid hemorrhage episode as the first manifestation of a carotid cavernous fistula , two years after a mild traumatic event.

Two major categories and four types of carotid cavernous fistulas have been described, according to their etiology and arterial supply to the fistulas ${ }^{1}$ : Direct (type A), which usually results from traumatic events and indirect, which might be subdivided according to its arterial supply in types B (exclusively from the ICA) $C$ (exclusively from the external carotid artery (ECA)) and D (from both, ICA and ECA). Traumatic fistulas are the most common forms of CCFs, resulting generally from fractures of the sphe-

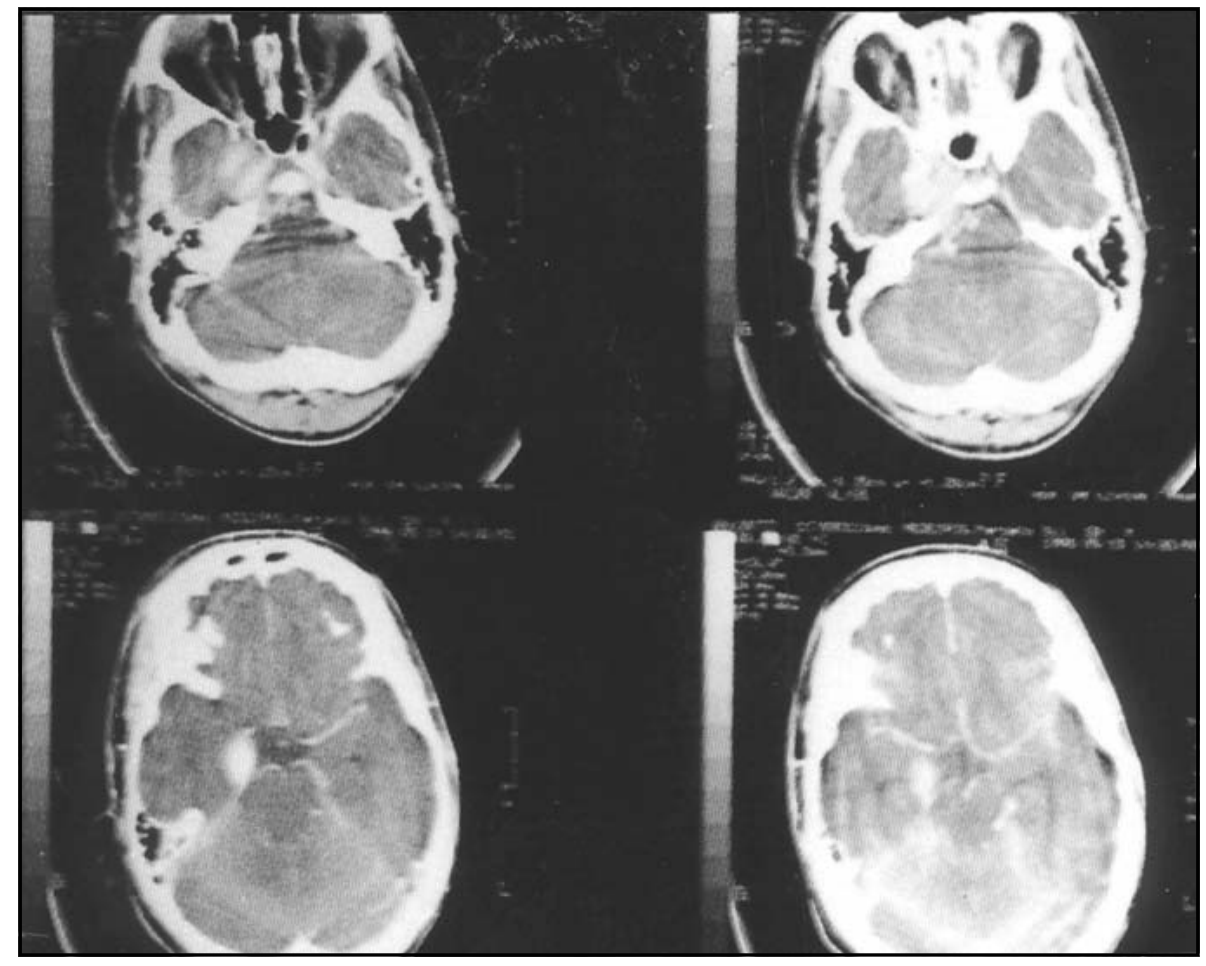

Fig 2. CT scan with contrast displaying the enhancement of a right paraselar lesion, which was first interpreted as a giant aneurysm. 


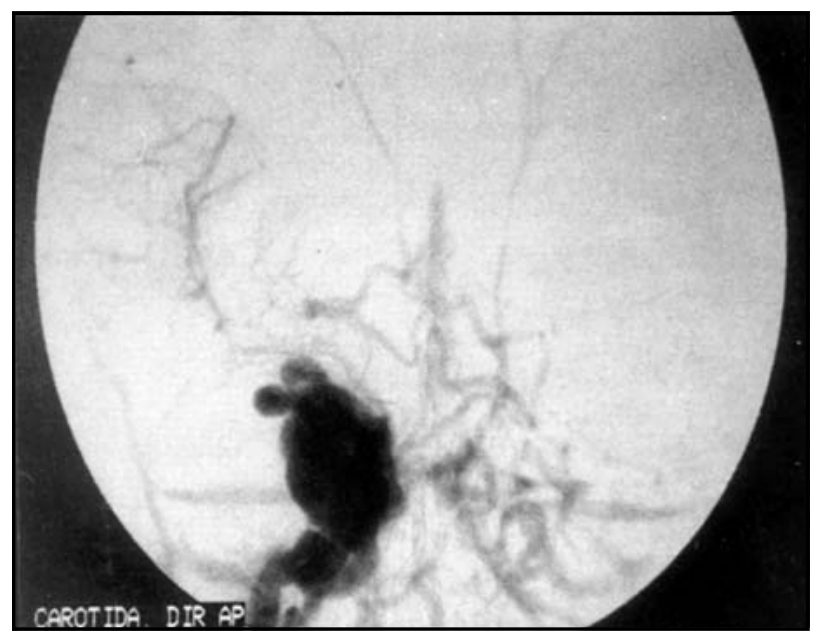

Fig 3. Cerebral angiography revealing the presence of a right carotid-cavernous fistula with retrograde venous drainage through the superior and inferior petrosal sinuses.

noid bone, which produce lesions in the cavernous segment of the ICA. Occasionally however, they may result from iatrogenic injuries, during endarterectomies, rhizotomies, biopsies, among others ${ }^{2,3}$.

Clinical manifestations of traumatic CCFs might range from asymptomatic to life-threatening conditions. Nevertheless, subtle paralysis of the third, fourth and sixth nerves, in conjunction to a series of ophthalmologic alterations related to an increase in the intraocular venous pressure and ischemia of the retina are frequently observed ${ }^{4,5}$.

Our patient presented a normal ophthalmologic exam, probably due to the absence of venous drainage from the fistula to the ophthalmic vein and the inversion of its regular flow, which filled the superior and inferior petrosal sinuses and several cortical vessels. Under these circumstances (cortical venous drainage), a state of chronic focal increased intracranial pressure generally occurs ${ }^{6}$. It is estimated that $10 \%$ of the patients that demonstrate cortical venous drainage evolve with some kind (most commonly fluctuating) of neurological deficits ${ }^{7}$. As these cortical veins are recruited, they start receiving their supply directly from the fistula, which leads to an important increase in their intraluminal pressure. Rupture of intracranial vessels is directly proportional to their intravascular pressure and inversely proportional to their wall thickness, according to Laplace's law. Therefore, increased levels of intraluminal pres- sure inside those thin vessels might have led to the subtle rupture of the cortical veins recruited by the fistula, culminating clinically with the subarachnoid hemorrhage episode experienced by the patient. Although subdural and subarachnoid hemorrhages have been rarely reported after carotid cavernous fistulas, the filling of cortical veins was prominent angiographic finding almost every time they occur ${ }^{6,8}$.

Spontaneous resolution of CCFs is a rare event, which prompts to the adoption of rapid therapeutic maneuvers. Due to its low morbidity and high index of arterial lumen preservation, endovascular procedures constitute the therapeutic modality of choice in most cases ${ }^{9-13}$. In our patient, closure of the fistula was successfully performed via a detachable balloon with satisfactory results and an excellent clinical recovery.

Our report aims to endorse the alertness concerning the diagnosis of CCFs after subarachnoid hemorrhages, and the tendency for this entity to occur in CCFs that present filling of cortical veins.

\section{REFERENCES}

1. Barrow DL, Spector RH, Braun IF, Landman J, Tindall SC, Tindall GT. Classification and treatment of spontaneous carotid-cavernous sinus fistulas. J Neurosurg 1985;62:248-256.

2. Barnwell SL, O'Neill. Lesions of cerebral veins and dural sinuses. In Youmans JR (ed). Neurological Surgery. Saunders 1996:1465-1490.

3. Wilkins RH. Natural history of intracranial vascular malformations: a review. Neurosurgery 1985;16:421-430.

4. Jorgensen JS, Gutthoff RF. 24 cases of carotid-cavernous fistulas: frequency, symptoms, diagnosis and treatment. Acta Ophthalmol 1985;63(Suppl. 173):67-71

5. Keltner JL, Satterfield D, Dublin AB, Lee BC. Dural and carotid cavernous fistulas. Ophthalmology 1987;94:1585-1600.

6. Halbach VV, Higashida RT, Hieshima GB, Reicher M, Norman D, Newton TH. Dural fistulas involving the cavernous sinus: results of treatment in 30 patients. Radiology 1987;163:437-442.

7. Lasjaunias P, Chiu M, Brugge RT, Tolia A, Hurth M, Bernstein M. Neurological manifestations of intracranial dural arteriovenous malformations. J Neurosurg 1986;64:724-730.

8. Halbach VV, Hiehsima GB, Higashida RT, Reicher M. Carotid cavernous fistula: indications of urgent treatment. Am J Roentgenol 1987;149:587-593.

9. Debrun G, Lacour P, Viñuela F, Fox AJ, Drake C, Caron JP. Treatment of 54 traumatic carotid-cavernous fistulas. J Neurosurg 1981;55:678692.

10. Pelz DM, Lownie SP, Fox AJ, Rosso D. Intracranial dural arteriovenous fistulae with pail venous drainage: combined endovascular-neurosurgical therapy may be curative. Can J Neurol Sci 1997;24:210-218.

11. Debrun G, Viñuela F, Fox AJ, Davis KR, Ahn HS. Indications for treatment and classification of 132 carotid-cavernous fistulas. Neurosurgery 1988;22:285-289.

12. Fournier D, Terbrugge KG, Willinsky R, LaSjaunias P, Montarena W. Endovascular treatment of intracerebral arteriovenous malformations: experience with 49 cases. J Neurosurg 1991;75:228-233.

13. Fox AJ, Pelz DM, Lee DH. Arteriovenous malformations of the brain: Recent results of endovascular therapy. Radiology 1990;177:51-57. 